\title{
UPAYA MENINGKATKAN HASIL BELAJAR MATEMATIKA DENGAN MODEL PEMBELAJARAN KOOPERATIF TIPE STUDENT ACHIEVMENT TEAM DIVISION (STAD) DI KELAS XI IPS 2 SMA NEGERI 11 PALEMBANG
}

\author{
Oleh: \\ Clementina Sidabutar \\ Guru SMA Negeri 11 Palembang \\ clementina.m.sidabutar@gmail.com
}

\begin{abstract}
ABSTRAK
Penelitian ini menggunakan penelitian tindakan kelas sebanyak dua siklus. Setiap siklus terdiri dari empat tahap yaitu: rancangan, kegiatan dan pengamatan, refleksi, dan revisi. Sasaran penelitian ini adalah peserta didik kelas XI IPS 2 di SMA Negeri 11 Palembang. Data yang diperoleh berupa hasil tes formatif, lembar observasi kegiatan belajar mengajar. Dari hasil analis didapatkan bahwa hasil belajar peserta didik mengalami peningkatan dari pra siklus sampai siklus II yaitu, pra siklus $(47,5 \%)$, siklus I (70\%) dan siklus II $(93,75 \%)$. Kesimpulan dari penelitian ini adalah Model Pembelajaran Kooperatif Tipe Student Achievment Team Division (STAD) dapat meningkatkan hasil belajar peserta didik kelas XI IPS 2 SMA Negeri 11 Palembang, serta model pembelajaran ini dapat digunakan sebagai salah satu alternatif pembelajaran Matematika.
\end{abstract}

Kata Kunci: Hasil belajar,Matematika, Student Achievment Team Division

\begin{abstract}
This study uses two cycles of classroom action research. Each cycle consists of four stages, namely: design, activity and observation, reflection, and revision. The target of this research is students of class XI IPS 2 at SMA Negeri 11 Palembang. The data obtained are in the form of formative test results, observation sheets of teaching and learning activities. From the results of the analysis, it was found that the learning outcomes of students had increased from pre-cycle to cycle II, namely, pre-cycle (47.5\%), cycle I (70\%) and cycle II (93.75\%). The conclusion of this study is that the Student Achievement Team Division (STAD) cooperative learning model can improve the learning outcomes of students in class XI IPS 2 SMA Negeri 11 Palembang, and this learning model can be used as an alternative to learning mathematics.
\end{abstract}

Keywords: Learning Outcomes, Mathematics, Student Achievement Team Division 


\section{PENDAHULUAN}

Matematika merupakan sebuah mata pelajaran yang diajarkan dari mulai jenjang Sekolah Dasar (SD) sampai Jenjang Sekolah Menengah Atas (SMA). Carl Friedrich Gauss menyatakan matematika sebagai "Ratunya Ilmu Pengetahuan". Maksudnya bahwa Matematika merupakan sumer dari ilmu yang lain dan pada perkembangannya tidak tergantung pada ilmu lain. Dengan kata lain ilmu-ilmu yang penemuan dan pengembangannya bergantung dari matematika.

Berdasarkan urgensi matematika sebagai sumber ilmu lainnya, maka setiap peserta didik diharapkan mampu untuk memahami dan menguasai mata pelajaran ini melalui pembelajaran yang mereka peroleh di setiap jenjang pendidikan. Dalam mata pelajaran matematika, terdapat materi program linier.

Program linier adalah suatu cara untuk penyelesaian masalah dengan menggunakan persamaan atau pertidaksamaan linier yang mempunyai banya penyelesaian, dengan memperhatikan syarat-syarat agar diperoleh hasil maksimum/minimum (penyelesaian optimum).

Berdasarkan pengalaman mengajar program linier merupakan salah satu materi matematika yang sulit dipahami peserta didik. Ini terkait materi pra syarat yang harus dikuasai peserta didik untuk mempelajari program linier. Misalnya sistem persamaan dan pertidak samaan linier. Peserta didik kadang berdalih bahwa materi prasyarat belm dipahami padahal materi itu sebenarnya telah ada di jenjang sebulumnya (SMP). Namun yang paing dominan muncul adalah kesulitan peserta didik memahami soal cerita sehingga berakibat pada rendahnya nilai hasil tes mereka. Hal ini dibuktikan dengan hasil tes tes materi program linier pada peserta didik kelas XI IPS 2 SMA Negeri 11 Palembang tahun pelajaran 2016/2017 dimana hanya 19 peserta didik dari 40 peserta didik yang mencapai KKM (65).

Untuk meningkatkan hasil belajar matematika materi program linier pada peserta didik kelas XI IPS 2 SMA Negeri 11 Palembang perlu di lakukan tindakan perbaikan model pembelajaran. Berdasarkan hasil penelitian yang pernah dilakukan terhadap model pembelajaran, salah 
satu model pembelajaran yang dapat efektif meningkatkan kemampuan berfikir peserta didik adalah model pembelajaran kooperatif (Suryadi, 1999: 128).

Dalam belajar kooperatif memungkinkan peserta didik terlibat aktif pada proses pembelajaran sehingga memberikan dampak yang positif terhadap kualitas interaksi dan komunikasi diantara peserta didik. Interaksi dan komunikasi yang berkualitas ini dapat memotivasi peserta didik sehingga meningkatkan hasil belajarnya. Peningkatan hasil belajar peserta didik juga dikarenakan pada strategi belajar kooperatif setiap anggota kelompok dituntutuntuk bertanggung jawab atas keberhasilan belajar baik seara individu maupun kelompok. Sedangkan Ros (1995) mengemukakan bahwa dengan adanya perbedaaan pendapat dan saling menjelaskan dari anggota kelompok yang lain, belajar kooperatif selalu mengingat dan menerapkan strategi pemecahan masalah dibandingkan dengan peserta didik yang bebas (Durren dan Cherrington :1992).

Salah satu model pembelajaran kooperatif adalah Student Teams
Achievement Division (STAD). Yaitu suatu pembelajaran kelompok beranggotakan 4-6 peserta didik, merupakan campuran laki-laki dan perempuan dengan tingkat kemampuan beragam. Pada pembelajaran kooperatif tipe STAD peserta didik selalu diberi motivasi untuk saling membantu dan saling membelajarkan teman sekelompoknya dalam memahami materi pelajaran, serta untuk menyelesaikan tugas akademik dalam rangka mencapai ketuntasan belajar yang maksimal (Slavin: 1995).

Berdasarkan latar belakang masalah yang dikemukakan diatas, maka yang menjadi permasalahan dalam penelitian ini adalah "apakah ada peningkatan hasil belajar matematika setelah diterpakannya model pembelajaran kooperatif tipe Student Teams Achievement Division (STAD) pada peserta didik kelas XI IPS 2 SMA Negeri 11 Palembang?”.

Sesuai dengan permasalahan diatas, maka tujuan dari penelitian ini adalah untuk meningkatkan hasil belajar matematika melalui model pembelajaran kooperatif tipe Student Teams Achievement Division (STAD) 
kelas XI IPS 2 SMA Negeri 11 Palembang.

Belajar adalah usaha sadar dan terncana yang dilakukan individu dalam pemerolehan pengetahuan dan keterampilan secara terus menerus sehingga terjadi perubahan tingkah laku dalam ranah kognitif, afektif dan psikomotorik berdasarkan pengalaman dan berinteraksi dengan lingkungannya menurut Prof. Dr. Z. Mawardi Effendi (2010:48).

Menurut slameto belajar adalah suatu proses usaha yang dilakukan seseorang untuk memperoleh suatu perubahan tingkah laku yang baru secara keseluruhan, sebagai hasil pengalamannya sediri dalam interaksi dengan lingkungannya (Salmeto, 2010:2)

Belajar menurut winkel adalah aktivitas mental/pisikis yang berlangsung dalam interaksi aktif dengan lingkungan yang menghasilkan perubahan-perubahan dalam pengetahuan, ketrampilan dan sikap Dr. Purwanto, M.Pd (2011:38).
Belajar merupakan sebuah proses yang kompleks yang terjadi pada semua orang dan berlangsung seumur hidup. Salah satu pertanda bahwa seseorang telah belajar sesuatu adalah adanya perubahan tingkahlaku dalam diri. Perubahan tingkah laku tersebut menyangkut perubahan yang bersifat pengetahuan (kognitif), dan keterampilan (pisikomotor), maupun yang menyangkut nilai dan sikap (afektif) (Siregar dan hartini, 2010:3).

Belajar dapat membawa suatu perubahan pada individu yang belajar. Perubahan ini merupakan pengalaman tingkah laku dari yang kurang baik menjadi lebih baik. Pengalaman dalam belajar merupakan pengalaman yang dituju pada hasil yang akan dicapai peserta didik dalam proses belajar di sekolah. Menurut Poerwodarminto (1991: 768), Hasil Belajar adalah hasil yang dicapai (dilakukan, dikerjakan), dalam hal ini Hasil Belajar merupakan hasil pekerjaan, hasil penciptaan oleh seseorang yang diperoleh dengan ketelitian kerja serta perjuangan yang membutuhkan pikiran.

Matematika diartikan oleh Johnson dan Rising (Erman Suherman, 2003: 19) sebagai pola 
berpikir, pola mengorganisasi, pembuktian yang logik, bahasa yang menggunakan istilah yang didefinisikan dengan cermat, jelas, dan akurat representasinya dengan simbol dan padat. Matematika menurut Erman Suherman (2003:253) adalah disiplin ilmu tentang tata cara berfikir dan mengolah logika, baik secara kuantitatif maupun secara kualitatif. Menurut Johnson dan Myklebust yang dikutip oleh Mulyono Abdurrahman (2002:252) matematika adalah bahasa simbiolis yang fungsi praktisnya untuk mengekspresikan hubunganhubungan kuantitatif dan keruangan sedangkan fungsi teoritisnya adalah untuk memudahkan berfikir. Menurut Permendiknas No. 22 Tahun 2006 (Depdiknas, 2006: 346) salah satu tujuan matematika pada pendidikan menengah adalah agar peserta didik memilki kemampuan memahami konsep matematika, menjelaskan keterkaitan antar konsep dan mengaplikasikan algoritma, secara lwes, akurat, efesien dan tepat dalam pemecahan masalah.
Pembelajaran kooperatif tipe STAD ini dikembangkan oleh Robert Slavina dan teman-temannya di universitas John Hopkin, dan merupakan salah satu model pembelajaran kooperatif yang paling sederhana. Slavina dalam Nur (2008:50) menjelaskan bahwa "Pembelajaran kooperatif dengan model STAD. Peserta didik ditempatkan dalam kelompok belajar beranggotakan emapt atau lima orang peserta didik yang merupakan campuran dari peserta didik berkemampuan tinggi, sedang dan rendah atauvariasi jenis kelamin, kelompok ras dan etnis, atau kelompok sosial lainnya.

Guru menggunakan STAD terlebih dahulu menyajikan materi baru dalam kelas, kemudian anggota team mempelajari dan berlatih untuk materi tersebut dalam kelompok mereka yang biasanya bekerja berpasangan. Aktivitas peserta didik yang dapat diamati selama pelaksanaan STAD adalah melengkapi lembar kerja, bertanya satu sama lain, membahas masalah dan mengerjakan latihnan.

$$
\text { Jenis penelitian yang }
$$

dilaksanakan adalah Penelitian 
Tindakan Kelas (PTK) atau Classroom Action Research (CAR). Penelitian tindakan kelas merupakan bentuk penelitian yang di lakukan secara langsung oleh guru. Dimana guru sangat berpengaruh sekali dalam proses penelitian tindakan kelas. Pada bentuk ini tujuan utama penelitian kelas ialah untuk meningkatkan hasil belajar pembelajaran dikelas. Dalam kegiatan ini, guru terlibat langsung secara penuh dalam proses perencanaan tindakan, observasi dan refleksi kehadiran pihak dalam penelitian ini perannya tidak dominan dan sangat kecil.

Penelitian ini dilaksankan di SMA Negeri 11 Palembang yang berlokasi JL. Inspektur Marzuki No.2552 Siring Agung, Ilir Barat I Kota Palembang Sumatera Selatan.

Penelitian dilaksanakan pada bulan Agustus sampai bulan Oktober semester ganjil tahun pelajaran 2016/2017. Subjek yang dimaksud tindakan dalam penelitian ini adalah peserta didik di kelas XI IPS 2 SMA Negeri 11 Palembanng yang berjumlah 40 peserta didik. Sedangkan partisipan yang terlibat dalam penelitian ini adalah teman sejawat.

Prosedur penelitian menggunakan prosedur Alur dari model Elliot diadopsi dari Atmono (2009:15), pada intinya akan mengidentifikasi perkembangan dan perubahan subyek setelah subyek diberikan perlakuan khusus atau dikondisi tertentu dalam kurun waktu tertentu dan berulang-ulang sampai program dinyatakan berhasil. Setiap siklus mencakup empat tahapan, yaitu perencanaan (Planning), pelaksanaan tindakan (action), pengamatan (observasi), dan refleksi, (reflection) seperti digambarkan berikut ini :

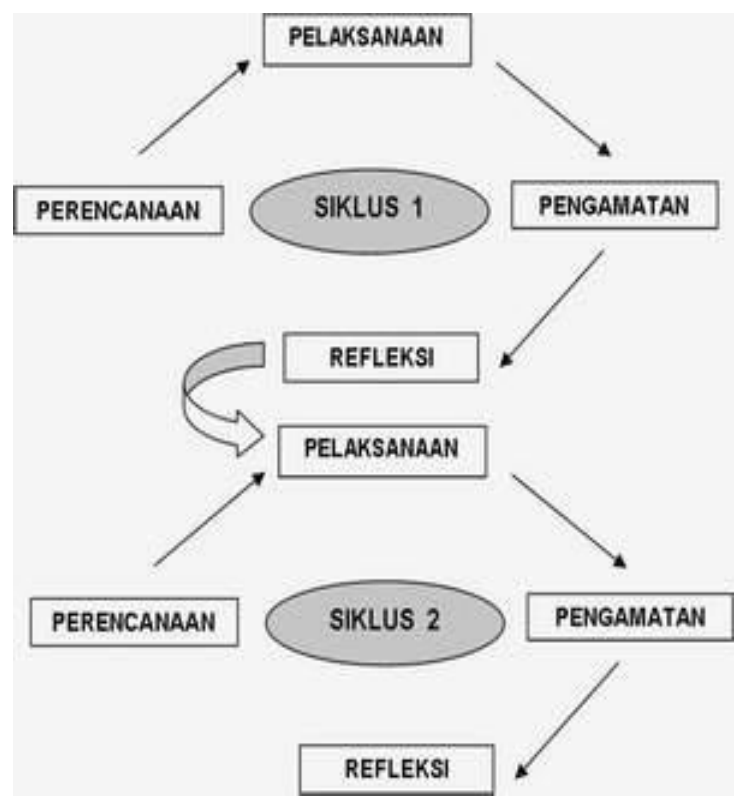

Gambar 1. Skema Alur PTK

Penelitian tindakan kelas dilaksanakan dalam empat langkah 
utama yaitu perencanaan, pelaksanaan tindakan, observasi (pengamatan) serta evaluasi dan refleksi. Empat langkah utama yang saling berkaitan itu dalam pelaksanaannya sering disebut dengan istilah satu siklus.

\section{HASIL DAN PEMBAHASAN}

\section{Siklus I}

Penyusunan Rencana Pelaksanaan

Pembelajaran (RPP).RPP disusun oleh penenliti dengan bimbingan pendidik. Adapun RPP yang digunakan selama pembelajaran dapat dilihat pada lampiran. Penyusunan Lembar Kegiatan Peserta Didik (LKPD). LKPD merupakan lembar kegiatan untuk peserta didik yang digunakan pada saat belajar kelompok. LKPD disusun oleh penenliti dengan bimbingan pendidik. Adapun LKPD yang digunakan selama pembelajaran dapat dilihat pada lampiran. Menyusun Lembar Observasi Pelaksanaan Pembelajaran

Kuis dilaksanakan setelah kegiatan belajar kelompok selesai. Kuis dilaksanakan secara individu dan untuk mengetahui pemahaman peserta didik terhadap materi yang sudah dipelajari. Kuis yang digunakan pada tiap siklus berupa tes uraian. Soal tes terdiri dari 3 butir soal. Tes tersebut digunakan untuk mengukur tingkat pemahaman konsep peserta didik..

Selama pelaksanaan tindakan berlangsung, observer melakukan observasi terhadap keseluruhan kegiatan yang terjadi selama berlangsungnya proses pembelajaran di kelas.

Berikut adalah gambaran hasil observasi yang telah dilakukan observer selama pembelajaran pada siklus I : Banyak peserta didik yang datang terlambat, sehingga proses pembelajaran dimulai tidak tepat waktu. Pendidik tertebih dahulu tidak menyampaikan tujuan pembelajaran yang harus dicapai peserta didik, tetapi langsung menjelaskan materi.Saat pembagian kelompok, ada beberapa peserta didik yang keberatan sehingga menghambat kegiatan pembelajaran.Saat belajar kelompok, peserta didik belum melaksanakan secara optimal. Masih banyak peserta didik yang hanya menggantungkan jawaban dari teman kelompoknya dan mengobrol dengan temannya dimana topik pembicaraan bukanlah materi yang sedang dipelajari.Saat kuis individu, masih banyak peserta didik yang berusaha untuk mencontek jawaban temannya. Berdasarkan keseluruhan tindakan siklus 
I meliputi perencanaan dan pelaksanaan tindakan serta hasil observasi yang dilakukan, dapat dilakukan hasil refleksi. Guru dan observer mendiskusikan hasil pelaksanaan tindakan dan hasil observasi. Berdasarkan hasil analisis pemahaman konsep peserta didik terhadap tes siklus I diketahui pencapaian KKM peserta didik sebesar $70 \%$ dan berdasarkan pedoman kualifikasi hasil tes yang telah ditentukan, persentase tersebut termasuk dalam kategori Sedang. Belum tercapainya hasil yang optimal disebabkan oleh permasalahanpermasalahan sebagai berikut :Kesadaran peserta didik kurang dan masih ada peserta didik yang tidak memperhatikan saat guru menjelaskan. Kerjasama dalam kelompok belum berjalan dengan optimal, karena para peserta didik masih terbiasa dengan model pembelajaran sebelumnya yaitu ekspositori, selain itu masih ada peserta didik yang hanya menunggu jawaban dari temannya. Manajemen waktu pelaksanaan pembelajaran oleh peneliti masih kurang. Hal itu menyababkan waktu yang digunakan untuk proses pembelajaran kurang.

\section{Siklus II}

Pada tahap perencanaan siklus II, secara umum kegiatan yang dilakukan peneliti sama dengan kegiatan perencanaan pada siklus I. Namun terdapat perbaikan pelaksanaan tindakan yang berdasarkan pada hasil refleksi siklus I yang telah diuraikan sebelumnya. Soal tes siklus II berupa tes uraian dan terdiri dari 3 butir soal.

Secara umum berikut adalah gambaran hasil observasi yang telah dilakukan oleh observer selama proses pembelajaran pada siklus II setelah diadakannya perbaikan berdasarkan tahap refleksi pada siklus sebelumnya : Ketika guru menerangkan, peserta didik memperhatikan dan mencatat hal-hal yang penting. Selain itu peserta didik antusias untuk bertanya jika masih ada materi yang belum jelas. Mereka termotivasi supaya bisa mendapatkan peningkatan skor individu yang nantinya akan berpengaruh pada nilai kelompok mereka dan mendapatkan hadiah.Peningkatan hasil skor kuis individu tidak hanya didomonasi oleh peserta didik tertentu. Interaksi anggota kelompok dalam belajar kelompok sudah lebih baik. Mereka terlebih dahulu bertanya kepada teman sekelompoknya 
dan baru bertanya pada guru jika mereka tidak menemukan solusinya. Ketidakcocokkan pembagian kelompok seperti pada siklus I sudah tidah terjadi lagi. Dengan perhatian dan pengawasan lebih yang diberikan peneliti terutama ketika proses belajar kelompok, proses belajar kelompok pada siklus II sudah berjalan lebih baik. Peserta didik yang tadinya hanya menyalin jawaban teman, kini ikut terlibat dalam diskusi kelompok. Pada siklus II ini guru memberikan batasan waktu yang lebih jelas untuk setiap kegiatan peserta didik selama proses pembelajaran. Sehingga LKPD yang sudah didiskusikan secara kelompok bisa dipresentasikan dengan lebih optimal dari sebelumya.

Berdasarkan keseluruhan tindakan siklus II meliputi perencanaan dan pelaksanaan tindakan serta hasil observasi yang dilakukan, dapat dilakukan hasil refleksi. Dari hasil observasi siklus II dapat dikatakan bahwa proses pembelajaran sudah menunjukan hasil yang optimal. Berdasarkan hasil analisis pemahaman konsep peserta didik terhadap tes siklus II diketahui rata-rata persentase pencapaian KKM Klasikal di kelas XI IPS 2 SMA Negeri 11 Palembang sebesar $93,75 \%$ dan berdasarkan pedoman kualifikasi hasil tes yang telah ditentukan, persentase tersebut termasuk dalam kategori tinggi. Rata-rata persentase pemahaman komsep peserta didik tersebut meningkat dari siklus I yang diketahui sebesar $70 \%$.

Tindakan pada siklus II yang sudah diperbaiki berdasarkan hasil refleksi dari siklus I yaitu mengoptimalkan interaksi antar peserta didik dan kerjasama dalam kelompok terbukti bisa mengatasi permasalah peningkatan skor hasil kuis individu yang didominasi peserta didik tertentu. Hal itu bisa dilihat dari peningkatan skor individu yang sudah merata. Selain itu perasaan tidak cocok dengan teman kelompoknya sudah tidak terjadi lagi sehingga interaksi kelompok terjadi lebih baik.

Berdasarkan uraian tersebut disimpulkan bahwa penerapan model pembelajaran kooperatif tipe student teams achievement divisions (STAD) dapat meningkatkan hasil belajar peserta didik pada materi program linier sehingga indikator keberhasilan yang telah ditetapkan pada bab III terpenuhi maka tindakan sudah dapat dihentikan. 
Pembahasan

Sebelum dilaksanakannya model pembelajaran kooperatif tipe Student Teams Achievement Divisions (STAD), guru hanya menggunakan metode ceramah dalam proses pembelajaran. Sehingga hasil belajar peserta didik masih rendah yaitu hanya 19 peserta didik dari 40 peserta didik yang tuntas belajar atau hanya $47,50 \%$.

Dan secara umum setelah diterapkannya model pembelajaran kooperatif tipe Student Teams Achievement Divisions (STAD) pada siklus I dan siklus II, sudah sesuai dengan tahapan-tahapan pada pedoman observasi yang sudah disusun peneliti sebelumnya. Pada siklus I, penerapan model pembelajaran kooperatif tipe Student Teams-Achievement

Divisions (STAD) masih belum bisa meningkatkan hasil belajar dengan maksimal, dimana baru $70 \%$ (kategori sedang) peserta didik yang mencapai KKM Klasikal. Hal tersebut menunjukan bahwa indikator kinerja yang telah ditetapkan pada bab III yaitu sebesar $85 \%$ peserta didik mencapai KKM belum tercapai.
Hal ini disebabkan oleh tingkat kesulitan soal dan interaksi peserta didik saat proses pembelajaran pada siklus I belum optimal. Interaksi antar peserta didik berpengaruh pada kemampuan mengaplikasikan program linier dua varibel dalam pemecahan masalah karena menurut Dewey dalam Oxford (1997) interaksi antar peserta didik tersebut membuat peserta didik melakukan proses sosial seperti saling berpendapat serta saling menjelaskan dalam mengkonstruksi konsep yang menjadi tujuan pembelajaran sehingga konsep tersebut akan bermakna bagi peserta didik. Jika peserta didik memaknai konsep tersebut maka peserta didik akan cenderung lebih mudah dalam mengaplikasikan program linier dua variabel dalam pemecahan masalah.

Pada siklus II, inikator kinerja telah tercapai yaitu peserta didik yang mencapai KKM Klasikal sebesar 93.75\%. Hal ini karena kemapuan peserta didik untuk memahami materi sudah meningkat, terbukti dalam hasil observasi pada siklus II peserta didik dengan antusias mencatat dan mendengarkan semua penjelasan 
guru. Selain itu interaksi antar peserta didik dalam kelompok sudah lebih baik, peserta didik yang tidak paham tanpa sungkan bertanya dengan teman satu kelompoknya yang lebih mengerti sehingga kemampuan peserta didik lebih merata dalam tiap kelompok.

Adapun grafik peningkatan hasil belajar peserta didik dari nilai pada pra siklus, siklus I sampai Siklus II :

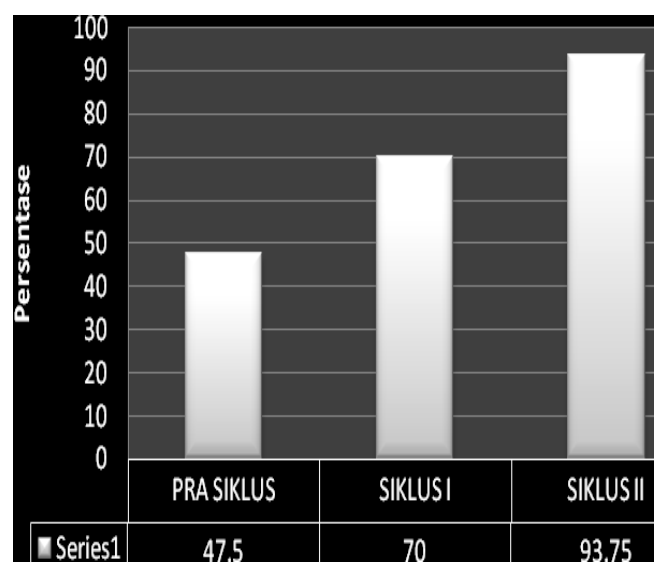

Gambar .2 Pencapain Hasil Belajar

\section{Peserta Didik}

\section{SIMPULAN}

Dari hasil kegiatan pembelajaran yang telah dilakukan selama dua siklus, dan berdasarkan seluruh pembahasan serta analisis yang telah dilakukan dapat disimpulkan bahwa penerapan pembelajaran kooperatif tipe Student Teams Achievement Divisions (STAD) tersebut dapat meningkatkan hasil belajar matematika pada materi program linier pada peserta didik kelas XI IPS 2 SMA Negeri 11 Palembang. Peningkatan tersebut ditunjukkan dengan meningkatnya pencapaian KKM Peserta didik dari pra siklus, siklus I samapi siklus II, yaitu pada pra siklus (sebelum menggunakan model pembelajaran kooperatif tipe STAD) pencapaian KKM klasikal peserta didik hanya sebesar $(47,5 \%)$, setelah dieterapkannya model pembelajaran kooperatif tipe STAD pada siklus I pencapaian KKM klasikal sebesar $(70 \%)$ walaupun belum optimal namun sudah menunjukan peningkatan yang cukup pesat dan pada siklus II pencapaian KKM klasikal mencapai 93,75\%. Angka tersebut berarti telah tercapainya indikator keberhasilan yang di tetapkan dalam penelitian ini sebesar $85 \%$.

Perlu adanya persiapan yang matang dalam melaksanakan model kooperatif tipe Student Teams Achievement Divisions (STAD), sehingga guru harus mampu menentukan atau memilih topik yang benar-benar bisa diterapkan dengan model pembelajaran kooperatif tipe Student Teams Achievement Divisions (STAD) dalam 
proses belajar mengajar sehingga diperoleh hasil yang optimal. Model pembelajaran kooperatif tipe Student Teams Achievement Divisions (STAD) yang telah diterapkan di kelas XI IPS 2 SMA Negeri 11 Palembang bisa dijadikan sebagai salah satu alternatif untuk meningkatkan hasil belajar matematika pada materi yang lain.

\section{DAFTAR PUSTAKA}

Abdurahman, Mulyo. 2002. Pendidikan Bagi Anak Berkesulitan Belajar. Jakarta: PT. Asdi Maha Stya

Depdiknas. 2006. Peraturan Menteri Pendidikan Nasional Nomor 22 Tahun 2006. Tentang Standar Isi.

Erman Suherman, dkk. 2003. Strategi Pembelajaran Matematika Kontemporer. Bandung: UPI

Mawardi Efendi. 2010. Efektifitas Belajar. Jakarta: PT. Grafindo Persada

Miftah, Thoha. Perilaku Organisasi Konsep Dasar dan Aplikasinya. Jakarta. CV. Rajawali, 1983

Mohamad Nur. 2008. Pembelajaran Kooperatif. Surabaya: Pusat Sains dan Matematika Sekolah UNESA.

Purwanto. 2011. Teori-teori Belajar dan Pembelajaran. Bandung: Erlangga
Purwodarminta. 2007. Kamus Umum Bahasa Indonesia. Jakarta: Balai Pustaka

Ros. 1995. Pembelajaran Kooperatif. Bandung: ITB

Salvin, Robert E. 1995. Cooperative Learning Teori Riset dan Praktik. Bandung: Nusa Media

Slameto. 2010. Belajar dan Faktor-faktor yang Mempengaruhinya. Jakarta: Rineka Cipta

Siregar, Eveline dan Hartini Nara. Teori Belajar dan Pembelajaran. Bogor: Ghalia Indonesia, 2010.

Suryadi. 1999. Kurikulum dan Pembelajaran. Bandung: Bumi Aksar 